DOI: https://doi.org/10.24127/ajpm.v8i1.1573

\title{
EFEKTIVITAS MODEL LEARNING CYCLE 7E BERBANTUAN E-MODUL UNTUK MENINGKATKAN KEMAMPUAN BERPIKIR KRITIS PESERTA DIDIK SMP
}

\author{
Sapta Desty Sugiharti ${ }^{1}$, Nanang Supriadi ${ }^{2}$, Siska Andriani ${ }^{3}$ \\ 1,2,3 Pendidikan Matematika, Universitas Islam Negeri Raden Intan Lampung \\ E-mail: $\quad$ sapta.desty.s@gmail.com ${ }^{1)}$, \\ nanangsupriadi@gmail.com ${ }^{2)}$, \\ siskaandriani@radenintan.ac.id ${ }^{3)}$
}

Received 9 Oktober 2018, Received in revised 3 March 2019, Accepted 2 May 2019

\begin{abstract}
This research aimed to findout the effectiveness of learning cycle 7e assisted e-modul to improve critical thinking skill of Junior High School of students. This research used the quasy experimental design with three classed as sample, VII A as first experiment class, VII B as second experiment class, and VII C as control class. The data were used in this research are the result of pretest and n-gain scores. Data were analyzed by one way Anova and Scheffe test. Based on the result of the Scheffe test, it is known the models learning is to give the impact of a diffirent order to enhance the ability of the critical thinking skill. The mean of $\mathrm{N}$-Gain at first experiment class was 0,829, at second experiment class was 0,693, and control class was 0,571. Based on the mean of N-Gain, it can be concluded that learning cycle 7e assisted emodul was the most effective model to improve critical thinking skill of Junior High School students.
\end{abstract}

Keywords: critical thinking skill; e-modul; learning cycle 7 e.

\section{PENDAHULUAN}

Matematika merupakan pelajaran yang penting dan termasuk pelajaran yang menjadi standar untuk diujikan ketika akan melanjutkan ke jenjang pendidikan yang lebih tinggi, oleh sebab itu jam pelajaran matematika lebih banyak dibandingkan dengan pelajaran lainnya (Purwanti, 2016). Matematika juga mempunyai potensi besar untuk menjalankan peran dalam menyiapkan sumber daya manusia yang cakap, berpikir kritis, logis, inisiatif, dan kreatif terhadap perubahan dan perkembangan zaman (Ramdan, 2018). Meskipun matematika menjadi pelajaran yang penting dan sering dipelajari di sekolah, keinginan peserta didikuntuk mempelajari matematika tetap rendah.

Berdasarkan hasil wawancara yang dilakukan dengan peserta didik di SMP Negeri 22 Pesawaran Provinsi
Lampung diketahui beberapa hal yang menyebabkan rendahnya keinginan peserta didik untuk mempelajari matematika yaitu: peserta didik beranggapan matematika sebagai pelajaran yang sulit, banyaknya rumusrumus matematika yang harus dihafal, dan kegiatan pembelajaran matematika dimana pendidik menjelaskan materi pembelajaran dan peserta didik mendengarkan lalu mencatat materi tersebut menyebabkan peserta didik merasa bosan. Selain itu, diketahui bahwa kemampuan berpikir kritis peserta didik di sekolah tersebut masih rendah dan berdampak pada rendahnya kemampuan peserta didik untuk menyelesaikan permasalahan matematika serta rendahnya nilai matematika yang diperoleh peserta didik. Hal ini dapat dilihat pada nilai ujian akhir semester pada Tabel 1. 
DOI: https://doi.org/10.24127/ajpm.v8i1.1573

Tabel 1. Nilai Ujian Akhir Semester Ganjil Tahun Pelajaran 2017/2018

\begin{tabular}{ccccc}
\hline & & \multicolumn{2}{c}{ Nilai } & \\
\cline { 3 - 4 } No. & Kelas & $<\mathbf{7 0}$ & $\mathbf{2 7 0}$ & Jumlah Peserta Didik \\
\hline 1. & VII A & 10 & 22 & 32 \\
2. & VII B & 15 & 17 & 32 \\
3. & VII C & 18 & 14 & 32 \\
4. & VII D & 22 & 10 & 32 \\
5. & VII E & 19 & 13 & 32 \\
6. & VII F & 24 & 8 & 32 \\
\hline & Jumlah & 108 & 74 & 192 \\
\hline
\end{tabular}

Berdasarkan Tabel 1 diketahui bahwa hanya 74 peserta didik atau $38,5 \%$ dari jumlah peserta didik kelas VII di SMP Negeri 22 Pesawaran Provinsi Lampung yang memperoleh nilai ujian akhir semester ganjil lebih dari 70, sedangkan 108 peserta didik lainnya memperoleh nilai ujian akhir semester ganjil kurang dari 70. Hal ini disebabkan peserta didik rendahnya kemampuan berpikir kritis peserta didik dalam menyelesaikan soal matematika yang terdapat dalam ujian akhir semester ganjil.

Kegiatan pembelajaran matematika yang sering digunakan pendidik menyebabkan peserta didik merasa bosan dan akhirnya tidak memperhatikan materi pembelajaran yang disampaikan. Selain menyebabkan peserta didik merasa bosan, kegiatan pembelajaran tersebut juga menyebabkan peserta didik sulit untuk memahami materi pembelajaran serta cepat melupakan materi yang baru dipelajarinya, karena belajar seharusnya merupakan proses aktif dari peserta didik dalam membangun pengetahuannya, bukan proses pasif yang hanya menerima kucuran ceramah pendidik tentang pengetahuan (Syazali, 2015). Kuncuran ceramah tentang pengetahuan menyebabkan rendahnya kemampuan berpikir kritis peserta didik karena peserta didik terbiasa hanya menerima tanpa mau mencari dan memahami materi pembelajaran. Kemampuan berpikir kritis merupakan salah satu kemampuan yang penting dalam pembelajaran matematika baik untuk menyelesaikan permasalahan matematika ataupun untuk menyelesaikan permasalahan lainnya. Menggunakan model pembelajaran yang bervariasi dan tepat dapat menjauhkan peserta didik dari rasa bosan selama proses pembelajaran serta akan meningkatkan rasa ketertarikan peserta didik dan membawa mereka ke dalam matematika (Laswadi, 2015). Model pembelajaran adalah prosedur sistematik yang dikembangkan berdasarkan teori dan digunakan dalam mengorganisasikan proses pembelajaran (Sani, 2014). Model pembelajaran yang menuntut peserta didik untuk aktif selama proses pembelajaran dapat menjauhkan peserta didik dari rasa bosan dan dapat meningkatkan kemampuan berpikir kritis, salah satu model pembelajaran yang dapat digunakan yaitu learning cycle $7 e$.

$$
\text { Model learning cycle }
$$
dikembangkan oleh J. Myron Atkin, Robert Karplus, dan kelompok SCIS (Science Curriculum Improvement Study), di Universitas California, Berkeley, Amerika Serikat sejak tahun 1967 (Laelasari, 2014). Model pembelajaran ini berbasis konstruktiv 
yang berarti peserta didik membangun sendiri pengetahuannya melalui kegiatan pembelajaran yang aktif melalui interaksi dengan objek, fenomena, pengalaman, dan lingkungan. Model learning cycle dikembangkan menjadi tujuh fase (dalam Aziz, 2013) yaitu elicit, engage, explore, explain, elaborate, evaluate, dan extend, learning cycle yang memiliki tujuh fase inilah yang disebut model learning cycle $7 e$ (Eisenkraft, 2003).

Penggunaan model learning cycle $7 e$ memiliki kelebihan yaitu bersifat student centered yang menjadikan peserta didik sebagai pusat pembelajaran, dimana peserta didik akan melakukan investigasi dan penemuan untuk mencari dan memahami materi baru (Agustyaningrum, 2011). Selain melakukan investigasi dan penemuan, peserta didik juga diminta untuk menggali kembali materi pembelajaran lain yang mungkin berhubungan dengan materi baru yang dipelajarinya, peserta didik berlatih untuk menemukan konsep bukan untuk menghafal serta menyampaikanmateri baru yang telah ditemukannya.Seluruh fase dalam model learning cycle $7 e$ menuntut peserta didik untuk aktif dan berpikir kritis dalam mencari, memahami, dan menyampaikan materi baru yang dipelajarinya.

Peserta didik dikatakan berpikir kritis apabila peserta didik tersebut memperoleh suatu pengetahuan dengan cara hati-hati, tidak menerima begitu saja dari pendidik tetapi mempertimbangkan menggunakan penalaran, sehingga pengetahuan tersebut terpercaya dan dapat dipertanggungjawabkan (Abdullah, 2013). Hal ini sejalan dengan model learning cycle $7 e$ dimana peserta didik dilatih mencari dan memahami materi baru dan mengkaitkannya dengan materi yang telah dimilikinya. Membaca menjadi salah satu cara bagi peserta didik untuk mencari dan memahami materi baru. E-modul menjadi salah satu bahan belajar yang dapat digunakan peserta didik untuk belajar secara mandiri dan melatih peserta didik untuk berpikir dalam memahami materi baru. E-modul merupakan bagian dari electronic based e-learning yang memanfaatkan TIK, terutama perangkat yang berupa elektronik (Damarsasi, 2013). Komputer dan smartphone dapat menjadi sarana untuk menampilkan $e$ modul, hal ini dapat mengatasi terbatasnya jumlah modul cetak serta dari segi ekonomi lebih efisien karena tidak membutuhkan biaya untuk pencetakkan dan penggandaan (Lestari, 2015).

Model learning cycle $7 e$ juga telah dilaksanakan oleh Widoratih, Enawaty, dan Lestari (2016) didapatkan kesimpulan bahwa hasil belajar peserta didik yang menggunakan model learning cycle $7 e$ lebih tinggi dibandingkan peserta didik yang diberi pembelajaran menggunakan model konvensional. Berdasarkan penelitian tersebut diketahui bahwa model learning cycle $7 e$ memberikan dampak positif terhadap hasil belajar peserta didik, sedangkan pada penelitian bertujuan untuk melihat efektivitas model learning cycle $7 e$ yang ditambahkan penggunaan e-modul sebagai bahan belajar pengganti buku cetak yang telah ada untuk meningkatkan kemampuan berpikir kritis peserta didik.

Berdasarkan permasalahan tersebut maka tujuan penelitian ini yaitu untuk mengetahui efektivitas model learning cycle $7 e$ berbantuan e-modul untuk meningkatkan kemampuan berpikir kritis peserta didik SMP. 


\section{METODE PENELITIAN}

Metode yang digunakan dalam penelitian ini adalah quasy experimental designdengan desain pretest-posttest control design. Sampel dalam penelitian ini adalah tiga kelas di SMP Negeri 22 Pesawaran Provinsi Lampung yang diambil menggunakan teknik cluster random sampling, yaitu kelas VII A yang berjumlah 32 peserta didik, kelas VII B yang berjumlah 32 peserta didik, dan kelas VII C yang berjumlah 32 peserta didik. Ketiga kelas tersebut dibagi menjadi kelas eksperimen dan kelas kontrol serta akan menggunakan tiga model pembelajaran yang berbeda, kelas VII A sebagai kelas eksperimen1 akan menggunakan model learning cycle $7 e$ berbantuan $e$-modul, kelas VII B sebagai kelas eksperimen2 akan menggunakan model learning cycle $7 e$, dan kelas VII C sebagai kelas kontrol akan menggunakan model konvensional. Selanjutnya ketiga kelas tersebut digunakan untuk melihat manakah model pembelajaran yang lebih efektif untuk meningkatkan kemampuan berpikir kritis peserta didik.

Sampel penelitian akan diberikan pretest dan posttest berupa enam butir soal essay materi himpunan yang berpedoman pada empat indikator kemampuan berpikir kritis menurut Facion, yaitu interpretasi, analisis, evaluasi, dan inferensi (Normaya, 2015). Pretest akan diberikan sebelum ketiga kelas melaksanakan kegiatan pembelajaran yang bertujuan untuk mengetahui apakah ada perbedaan kemampuan awal berpikir kritis ketiga kelas sampel penelitian, dilanjutkan dengan kegiatan pembelajaran sesuai dengan model pembelajaran yang telah ditentukan dan penelitian diakhiri dengan pemberian posttest untuk mengetahui peningkatan kemampuan berpikir kritis peserta didik.
Instrumen penelitian yang digunakan yaitu enam butir soal essay materi himpunan yang merupakan soal esai yang valid, reliabel, tingkat kesukaran soal terlalu mudah, sedang, dan terlalu sukar serta memiliki daya beda cukup. Masing-masing butir soal memiliki skor 16 sehingga untuk memperoleh nilai setiap sampel digunakan rumus sebagai berikut:

$$
\text { Nilai }=\frac{\text { Skor Perolehan }}{96} \times 100
$$

Hasil pretest dan posttest digunakan untuk mengetahui n-gain atau peningkatan kemampuan berpikir kritis peserta didik yang dapat dihitung menggunakan rumus yang dikembangkan oleh Meltezer sebagai berikut (Dewi, 2017):

$$
g=\frac{S_{\text {posttest }}-S_{\text {pretest }}}{S_{\text {max }}-S_{\text {pretest }}}
$$

Keterangan:

$$
\begin{array}{ll}
\mathrm{g} & : \text { indeks gain } \\
S_{\text {max }} & \text { : nilai test maksimal } \\
S_{\text {pretest }} & : \text { nilai test awal } \\
S_{\text {posttest }} & : \text { nilai test akhir } \\
\text { Hasil pretest dan } \quad \text { n-gain }
\end{array}
$$

kemudian dianalisis menggunakan uji Lilifors untuk melihat apakah data berdistribusi normal dan uji Bartlett untuk melihat apakah data homogen, apabila data berditribusi normal dan homogen dilanjukan dengan uji Anova klasifikasi satu arah. Hasil pretest digunakan untuk mengetahui adakah perbedaan kemampuan awal berpikir kritis ketiga kelas sampel penelitian dan hasil n-gain digunakan untuk mengetahui adakah perbedaan peningkatan kemampuan berpikir kritis ketiga kelas sampel penelitian. Apabila ada perbedaan dari hasil uji Anova klasifikasi satu arah maka uji dilanjutkan menggunakan uji Scheffe. 
DOI: https://doi.org/10.24127/ajpm.v8i1.1573

\section{HASIL PENELITIAN DAN PEMBAHASAN}

Setelah didapatkan hasil pretest dari ketiga kelas tersebut, data hasil pretest diuji menggunakan uji Lilifors dan uji Bartlettdiperoleh hasil bahwa data hasil pretestberdistribusi normal dan homogen, kemudian dilanjutkan dengan uji Anova klasifikasi satu arah diperoleh hasil pada Tabel 2.

Tabel 2. Uji Anova Hasil Pretest Kemampuan Berpikir Kritis

\begin{tabular}{cccc}
\hline Kelas & Rata-Rata & F $_{\text {hitung }}$ & F $_{\text {tabel }}$ \\
\hline Eks1 & 26,807 & & \\
Eks2 & 25,066 & 2,02858 & 3,094 \\
Kontrol & 23,438 & & \\
\hline
\end{tabular}

Berdasarkan Tabel 2 diketahui bahwa rata-rata hasil pretest kelas eksperimen1 sebesar 26,807, kelas eksperimen2 sebesar 25,066, dan kelas kontrol sebesar 23,438. Uji Anova terhadap hasil pretest diperoleh $\mathrm{F}_{\text {hitung }}=2,02858$ sedangkan $F_{\text {tabel }}=3,094$, karena nilai $F_{\text {hitung }}<\mathrm{F}_{\text {tabel }}$ berarti rata-rata kemampuan awal berpikir kritis ketiga kelas yang menjadi sampel penelitian adalah sama.

Penelitian dilanjutkan dengan kegiatan pembelajaran sesuai dengan modelpembelajaran yang telah ditentukan sebelumnya. Penelitian diakhiri dengan posttest untuk mengetahui kemampuan akhir berpikir kritis peserta didik serta untuk mengetahui peningkatan kemampuan berpikir kritis peserta didik. Hasil $n$ gain atau peningkatan kemampuan berpikir kritis kemudian dianalisis menggunakan uji Anova untuk mengetahui adakah perbedaan rata-rata peningkatan kemampuan berpikir kritis ketiga kelas yang menjadi sampel penelitian. Berikut hasil uji Anova terhadap $n$-gain kemampuan berpikir kritis:

Tabel 3. Uji Anova $N$-Gain Kemampuan Berpikir Kritis

\begin{tabular}{lccc}
\hline \multicolumn{1}{c}{ Kelas } & Rata-Rata & $\mathbf{F}_{\text {hitung }}$ & $\mathbf{F}_{\text {tabel }}$ \\
\hline Eks1 & 0,829 & & \\
Eks2 & 0,693 & 53,70533 & 3,094 \\
Kontrol & 0,571 & & \\
\hline
\end{tabular}

Berdasarkan Tabel 3 diketahui bahwa rata-rata n-gain kelas eksperimen1 sebesar 0,829, kelas eksperimen2 sebesar 0,693, dan kelas kontrol sebesar 0,571. Uji Anova terhadap hasil $n$-gaindiperoleh $\mathrm{F}_{\text {hitung }}=$ 53,70533 sedangkan $\mathrm{F}_{\text {tabel }}=3,094$, karena nilai $\mathrm{F}_{\text {hitung }}>\mathrm{F}_{\text {tabel }}$ berarti ratarata peningkatan kemampuan berpikir kritis ketiga kelas tidak sama atau ketiga model pembelajaran memberikan dampak yang berbeda terhadap peningkatan kemampuan berpikir kritis peserta didik.
Untuk mengetahui model pembelajaran yang lebih efektif untuk meningkatkan kemampuan berpikir kritis dilakukan uji lanjut menggunakan uji Scheffe. Kelas eksperimen 1 dinyatakan sebagai $\mu_{1}$, kelas eksperimen2 dinyatakan sebagai $\mu_{2}$, dan kelas kontrol dinyatakan sebagai $\mu_{3}$. Berikut hasil uji Scheffe terhadap $n$ gain kemampuan berpikir kritis disajikan pada Tabel 4. 
DOI: https://doi.org/10.24127/ajpm.v8i1.1573

Tabel 4. Uji ScheffeN-Gain Kemampuan Berpikir Kritis

\begin{tabular}{ccc}
\hline Komparasi & $\boldsymbol{F}_{\boldsymbol{i}-\boldsymbol{j}}$ & $\boldsymbol{F}_{\text {tabel }}$ \\
\hline$F_{\mu_{1}-\mu_{2}}$ & 32,06769 & 3,996 \\
$F_{\mu_{1}-\mu_{3}}$ & 87,67325 & 3,996 \\
$F_{\mu_{2}-\mu_{3}}$ & 26,79326 & 3,996 \\
\hline
\end{tabular}

Berdasarkan Tabel 4 diketahui bahwa komparasi $F_{\mu_{1}-\mu_{2}}$ memiliki besar $F_{i-j}=$ 32,06769 sedangkan $F_{\text {tabel }}=3,996$ karena $F_{i-j}>F_{\text {tabel }}$ berarti rata-rata peningkatan kemampuan berpikir kritis kelas eksperimen1 dan kelas eksperimen2 tidak sama. Komparansi $F_{\mu_{1}-\mu_{3}}$ memiliki besar $F_{i-j}=87,67325$ sedangkan $F_{\text {tabel }}=3,996$ karena $F_{i-j}>F_{\text {tabel }}$ berarti rata-rata peningkatan kemampuan berpikir kritis kelas eksperimen1 dan kelas kontrol tidak sama. Komparansi $F_{\mu_{2}-\mu_{3}}$ besar $F_{i-j}=26,79326$ sedangkan $F_{\text {tabel }}=$ 3,996 karena $F_{i-j}>F_{\text {tabel }}$ berarti ratarata peningkatan kemampuan berpikir kritis kelas eksperimen1 dan kelas kontrol tidak sama. Hasil uji Scheffe menunjukkan bahwa ketiga model pembelajaran yang digunakan memiliki dampak yang berbeda untuk meningkatkan kemampuan berpikir kritis peserta didik SMP, kelas eksperimen1 memiliki rata-rata peningkatan kemampuan berpikir kritis sebesar 0,829 yang lebih besar dibandingkan kelas eksperimen2 dan kelas kontrol.

Berdasarkan Tabel 3 diketahui bahwa nilai rata-rata n-gain kemampuan berpikir kritis kelas eksperimen1 lebih tinggi, hal ini menunjukkan penggunaan model learning cycle $7 e$ yang setiap fasenya menuntut peserta didik untuk mencari dan memahami materi sendiri memberikan dampak yang baik untuk peserta didik dalam mengembangkan kemampuan berpikir kritis. Selain itu dengan adanya e-modul dapat membantu peserta didik dalam mencari sumber materi dan memahami materi tersebut sesuai dengan kemampuan yang dimilikinya. Model learning cycle $7 e$ berbantuan e-modul baik untuk meningkatkan kemampuan berpikir kritis, akan tetapi model ini memiliki banyak fase sehingga dalam pelaksanaannya menuntut pendidik untuk merencanakan pembelajaran dengan lebih matang serta menuntut keseriusan peserta didik selama kegiatan pembelajaran agar seluruh fase dalam model learning cycle $7 e$ dapat terlaksana.

Penelitian yang dilakukan oleh Widoratih, Enawaty, dan Lestari (2016) diperoleh hasil bahwa peserta didik yang menggunakan model learning cycle $7 e$ memperoleh hasil belajar yang lebih tinggi, sedangkan pada penelitian ini peningkatan kemampuan berpikir kritis peserta didik yang menggunakan model learning cycle $7 e$ berbantuan $e$ modul lebih tinggi. Hasil penelitian ini sejalan dengan penelitian yang dilakukan oleh Widoratih, Enawaty, dan Lestari (2016) karena apabila peserta didik memiliki kemampuan berpikir kritis yang baik maka peserta didik tidak akan mengalami kesulitan dalam menyelesaikan persoalan konseptual matematika dan akhirnya hasil belajar peserta didik akan tinggi.

\section{KESIMPULAN DAN SARAN}

Berdasarkan analisis data hasil penelitian diperoleh kesimpulan bahwa model pembelajaran learning cycle $7 e$ berbantuan $e$-modul lebih efektif untuk meningkatkan kemampuan berpikir kritis peserta didik SMP dibandingkan 
model pembelajaran learning cycle $7 e$ dan model konvensional, serta model pembelajaran learning cycle $7 e$ lebih efektif untuk meningkatkan kemampuan berpikir kritis peserta didik SMP dibandingkan model pembelajaran konvensional. Model learning cycle $7 e$ berbantuan $e$-modul lebih efektif karena model ini menuntut peserta didik untuk mencari dan memahami materi pembelajaran sendiri dan hal tersebut meningkatkan kemampuan berpikir kritis karena peserta didik harus mencari materi menggunakan e-modul dan menghubungkan sendiri materi pembelajaran bukan hanya menerima seluruh materi pembelajaran dari pendidik.

$$
\text { Berdasarkan kesimpulan }
$$
tersebut, penggunaan model learning cycle 7eberbantuan e-modul dapat dijadikan salah satu alternatif untuk meningkatkan kemampuan berpikir kritis peserta didikkhususnya dalam kegiatan pembelajaran matematika, akan tetapi karena model pembelajaran ini memiliki banyak fase sehingga dibutuhkan pengaturan waktu dan persiapan yang matang oleh pendidik.

\section{DAFTAR PUSTAKA}

Abdullah, I. H. (2013). Berpikir Kritis Matematik. Delta-Pi: Jurnal Matematika dan Pendidikan Matematika, 2(1), 66-75.

Agustyaningrum, N. (2011). Implementasi Model Pembelajaran Learning Cycle 5E Untuk Meningkatkan Kemampuan Komunikasi Matematis Siswa Kelas IX B SMP Negeri 2 Sleman. Matematika Dan Pendidikan Karakter Dalam Pembelajaran. 376-387. Makalah Seminar Nasional Pendidikan Matematika FMIPA UNY Yogyakarta 03 Desember 2011.
Aziz, Z., Rusilowati, A., Sukisno, M. (2013). Penggunaan Model Pembelajaran Learning Cycle $7 E$ Untuk Meningkatkan Hasil Belajar Siswa SMP Pada Pokok Bahasan Usaha Dan Energi. UPEJ Unnes Physics Education Journal, 2(3), 31-39.

Damarsasi, D. G., Soeprodjo., Saptorini. (2013). Penerapan Metode Inkuiri Berbantuan E-Modul. Jurnal Inovasi Pendidikan Kimia, 7(2).

Dewi, E. P., dkk. (2017). Efektivitas Modul dengan Model Inkuiri untuk Menumbuhkan Keterampilan Proses Sains Siswa pada Materi Kalor. Tadris: Jurnal Keguruan dan Ilmu Pendidikan, 2(2). $105-110$

Eisenkraft, A. (2003). Expanding The 5E Model. The Science Teacher. Diakses di www.nsta.org.

Haryani, D. (2011). Pembelajaran Matematika Dengan Pemecahan Masalah Untuk Menumbuhkan Kemampuan Berpikir Kritis Siswa. 121-126. Makalah Seminar Nasional Pendidikan Matematika FMIPA UNY Yogyakarta 14 Mei 2011.

Laelasari., Subroto, T., Ikhsan K, Nurul. (2014). Penerapan Model Pembelajaran Learning Cycle $7 E$ Dalam Kemampuan Representasi Matematis Mahasiswa. Euclid, 1(2), 82-92.

Laswadi. (2015) Pendekatan Problem Solving berbantuan Komputer dalam Pembelajaran Matematika. Al-Jabar: Jurnal Pendidikan Matematika, 6(1), 33-41.

Lestari, N. W. E., Hadianto, P., Rokhmani, L. (2015). Pengembangan E-Modul Ekonomi pada Materi Uang dan Perbankan untuk Siswa Kelas X A SMA Negeri 1 Panggul Tenggalek Tahun Ajaran 2014/2015. Jurnal 
DOI: https://doi.org/10.24127/ajpm.v8i1.1573

Pendidikan Ekonomi (Economic Education Journal), 8(1), 18-27.

Normaya, K. (2015). Kemampuan Berpikir Kritis Siswa Dalam Pembelajaran Matematika Dengan Menggunakan Model Jucama di Sekolah Menengah Pertama. Jurnal Pendidikan Matematika FKIP Universitas Lambung Mangkurat, 3(1), 92-104.

Purwanti, R. D., Pratiwi, D. D., Rinaldi, A. (2016). Pengaruh Pembelajaran Berbantuan Geogebra terhadap Pemahaman Konsep Matematis ditinjau dari Gaya Kognitif. AlJabar: Jurnal Pendidikan Matematika, 7(1), 115-122.

Ramdan, Z. M. (2018). Analisis Self Confidence Terhadap Kemampuan Pemecahan Masalah Matematis Siswa SMK pada
Materi Barisan dan Deret. Aksioma: Jurnal Pendidikan Matematika FKIP Univ. Muhammadiyah Metro, 7(2), 171179.

Sani, R. A. (2014). Inovasi Pembelajaran. Bumi Aksara, Jakarta.

Syazali, M. (2015). Pengaruh Model Pembelajaran Creative Problem Solving Berbantuan Maple II Terhadap Kemampuan Pemecahan Masalah Matematis. Al-Jabar: Jurnal Pendidikan Matematika, 6(1), 91-98.

Widoratih, K., Enawaty, E., Lestari, I. (2016). Pengaruh Model Learning Cycle 7E Terhadap Hasil Belajar Kimia Siswa Kelas X SMA. Jurnal Pendidikan dan Pembelajaran, 5(9). 